\title{
Studi Evaluasi Implementasi Sistem Penjaminan Mutu Internal (SPMI) dalam Rangka Mewujudkan Budaya Mutu
}

\author{
I Made Pater ${ }^{1}$, I Made Yudana ${ }^{2}$, Nyoman Natajaya ${ }^{3}$ \\ ${ }^{123}$ Jurusan administrasi pendidikan Program pasca sarjana \\ Universitas pendidikan ganesha \\ Singaraja, Indonesia \\ e-mail: madpater08@gmail.com,made.yudana@undiksha.ac.id, \\ nyoman.natajaya@undiksha.ac.id
}

\begin{abstract}
Abstrak
Tujuan penelitian ini adalah untuk mengetahui: (1) efektivitas implementasi SPMI ditinjau dari komponen contex (X1) di SMKN 3 Singaraja; (2) efektivitas pelaksanaan implementasi SPMI ditinjau dari komponen input di SMKN 3 Singaraja; (3) efektivitas implementasi SPMI ditinjau dari komponen process di SMKN 3 Singaraja: (4) efektivitas implementasi SPMI di ditinjau dari komponen product SMKN 3 Singaraja; (5) efektivitas implementasi SPMI ditinjau dari komponen contex (X1), input, process, dan product di SMKN 3 Singaraja; (6) kendala yang menjadi penghambat pelaksanaan implementasi SPMI di SMKN 3 Singaraja; (7) solusi yang dilakukan sehingga implementasi SPMI di SMKN 3 Singaraja dapat lebih efektif. Penelitian dilaksanakan di SMKN 3 Singaraja menggunakan metode evaluasi CIPP. Pengambilan data dengan kuesioner yang diisi oleh 129 responden. Hasil penelitan menunjukkan: (1) efektivitas implementasi SPMI Singaraja ditinjau dari komponen contex (X1) di SMKN 3 Singaraja, masuk skor T positif; (2) efektivitas pelaksanaan implementasi SPMI ditinjau dari komponen input di SMKN 3 Singaraja, masuk skor T negatif; (3) efektivitas implementasi SPMI ditinjau dari komponen process di SMKN 3 Singaraja, masuk skor T positif: (4) efektivitas implementasi SPMI di ditinjau dari komponen product SMKN 3 Singaraja, masuk skor T positif; (5) efektivitas implementasi SPMI ditinjau dari komponen contex (X1), input, process, dan product di SMKN 3 Singaraja berdasarkan skor T pada kuadran Glickman masuk kategori efektif; (6) Kendala yang menjadi penghambat pelaksanaan implementasi SPMI di SMKN 3 Singaraja adalah: (a) belum adanya alokasi dana pasti untuk pelaksanaan PPEPP SPMI yang dikelola mandiri oleh TPMPS dan belum adanya ruang, alat, serta bahan pendukung pelaksanaan PPEPP; (7) Solusi yang dilakukan sehingga implementasi SPMI di SMKN 3 Singaraja dapat lebih efektif adalah: (1) mengalokasikan anggaran khusus untuk pelaksanaan PPEPP SPMI di SMKN 3 Singaraja yang dapat dikelola secara mandiri oleh TPMPS dan Menyediakan ruang, alat, dan bahan yang mendukung pelaksanaan PPEPP oleh TPMPS.
\end{abstract}

Kata-kata kunci: Evaluasi CIPP, Implementasi SPMI

\begin{abstract}
The purpose of this study was to determine: (1) the effectiveness of the implementation of SPMI in terms of the contex (X1) component in SMKN 3 Singaraja; (2) the effectiveness of the implementation of SPMI implementation in terms of the input components in SMKN 3 Singaraja; (3) the effectiveness of the SPMI implementation in terms of the process components in SMKN 3 Singaraja: (4) the effectiveness of the implementation of SPMI in terms of components of the SMKN 3 Singaraja product; (5) the effectiveness of SPMI implementation in terms of the contex (X1), input, process, and product components at SMKN 3 Singaraja; (6) the obstacles that hampered the implementation of the SPMI implementation at Singaraja 3 State Vocational School; (7) solutions made so that the implementation of SPMI in SMKN Singaraja 3 can be more effective. The study was conducted at SMKN 3 Singaraja using the CIPP evaluation method. Retrieval of data with questionnaires filled out by 129 respondents. The results of the research show: (1) the effectiveness of the Singaraja SPMI implementation in terms of the contex component (X1) in SMKN 3 Singaraja, entering a positive T score; (2) the effectiveness of the implementation of the implementation of SPMI in terms of the input component in SMKN 3 Singaraja, entering a negative T score; (3) the effectiveness of SPMI implementation in terms of the process components in SMKN 3 Singaraja, entering a positive $T$ score: (4) the effectiveness of SPMI implementation in terms of components of the SMKN 3 Singaraja product, entering a positive T score; (5) the effectiveness of SPMI implementation in terms of the contex (X1), input, process, and product components in SMKN 3 Singaraja based on the $T$
\end{abstract}


score in the Glickman quadrant in the effective category; (6) Obstacles that hamper the implementation of the implementation of SPMI in SMKN 3 Singaraja are: (a) there is no definite allocation of funds for the implementation of PPEPP SPMI which is managed independently by TPMPS and there is no space, tools, and supporting materials for PPEPP implementation; (7) The solutions made so that the implementation of SPMI in SMKN 3 Singaraja can be more effective are: (1) allocating a special budget for the implementation of PPEPP SPMI at SMKN 3 Singaraja that can be managed independently by TPMPS and Providing space, tools and materials that support implementation PPEPP by TPMPS.

Keywords: cipp evaluation, spmi implementation

\section{Pendahuluan}

Secara nasional, mutu pendidikan dasar dan menengah di Indonesia belum seperti yang diharapkan. Hasil pemetaan mutu pendidikan secara nasional pada tahun 2014 menunjukkan hanya sekitar $16 \%$ satuan pendidikan yang memenuhi standar nasional pendidikan (SNP). Sebagian besar satuan pendidikan belum memenuhi SNP, bahkan ada satuan pendidikan yang masih belum memenuhi standar pelayanan minimal (SPM).

Standar kualitas pendidikan yang ditetapkan oleh pemerintah berbeda dengan standar yang dilaksanakan oleh satuan pendidikan. Standar yang digunakan oleh sebagian besar sekolah jauh di bawah standar yang ditetapkan oleh pemerintah. Akibatnya, kualitas lulusan yang dihasilkan oleh satuan pendidikan belum memenuhi standar yang diharapkan. Kesenjangan antara hasil ujian nasional dengan hasil ujian sekolah yang lebar menunjukkan bahwa ada permasalahan dalam instrumen dan metode pengukuran hasil belajar siswa.

Upaya peningkatan mutu pendidikan ini tidak akan dapat diwujudkan tanpa ada upaya perbaikan dalam penyelenggaraan pendidikan menuju pendidikan bermutu. Untuk mewujudkan pendidikan bermutu ini, upaya membangun budaya mutu di satuan pendidikan menjadi suatu kebutuhan yang tidak dapat ditawar. Satuan pendidikan harus mengimplemetasikan penjaminan mutu pendidikan tersebut secara mandiri dan berkelanjutan.

Mutu pendidikan dasar dan menengah adalah tingkat kesesuaian antara penyelenggaraan pendidikan dasar dan menengah dengan Standar Nasional Pendidikan (SNP) pada satuan pendidikan dasar dan pendidikan menengah dan/atau program keahlian. Mutu pendidikan di satuan pendidikan tidak akan meningkat tanpa diiringi dengan penjaminan mutu pendidikan oleh satuan pendidikan. Penjaminan mutu pendidikan dasar dan menengah adalah suatu mekanisme yang sistematis, terintegrasi, dan berkelanjutan untuk memastikan bahwa seluruh process penyelenggaraan pendidikan telah sesuai dengan standar mutu dan aturan yang ditetapkan. Untuk dapat melakukan penjaminan mutu pendidikan dengan baik diperlukan adanya sistem penjaminan mutu pendidikan.

Merujuk Pasal 2 Undang-Undang Nomor 20 Tahun 2003 tentang Sistem Pendidikan Nasional ditegaskan bahwa pendidikan nasional berdasarkan Pancasila dan Undang-Undang Dasar Negara Republik Indonesia Tahun 1945. Selanjutnya dalam Pasal 3 dinyatakan bahwa pendidikan nasional berfungsi mengembangkan kemampuan dan membentuk watak serta peradaban bangsa yang bermartabat dalam rangka mencerdaskan kehidupan bangsa, dan bertujuan untuk mengembangkan potensi peserta didik agar menjadi manusia yang beriman dan bertakwa kepada Tuhan Yang Maha Esa, berakhlak mulia, sehat, berilmu, cakap, kreatif, mandiri, dan menjadi warga negara yang demokratis serta bertanggung-jawab. Pasal 2 ayat (1) Peraturan Pemerintah Nomor 19 Tahun 2005 tentang Standar Nasional Pendidikan mengamanatkan 8 (delapan) Standar Nasional Pendidikan, yaitu: standar kompetensi lulusan, standar isi, standar process pembelajaran, standar penilaian pendidikan, standar pendidik dan tenaga kependidikan, standar sarana dan prasarana, standar pengelolaan, dan standar biaya operasi. Untuk mewujudkan tujuan pendidikan nasional tersebut perlu dirumuskan kualifikasi kemampuan lulusan SMK/MAK yang dituangkan dalam standar kompetensi lulusan.

Pada Kemendikbud (2018) guna mewujudkan tujuan pendidikan kejuruan di atas diperlukan standar kompetensi lulusan SMK/MAK yang dijabarkan dari profil lulusan antara lain: (1) beriman, bertakwa, dan berbudi pekerti luhur; (2) memiliki sikap mental yang kuat untuk mengembangkan dirinya secara berkelanjutan; (3) menguasai ilmu pengetahuan teknologi dan seni serta memiliki keterampilan sesuai dengan kebutuhan pembangunan; (4) memiliki kemampuan producttif sesuai dengan bidang keahliannya baik untuk bekerja atau berwirausaha; dan (5) berkontribusi dalam pengembangan industri Indonesia yang kompetitif 
menghadapi pasar global. Profil lulusan tersebut dapat tercapai jika mengikuti minimal standar yang telah ditetapkan kemendikbud, yang disebut dengan standar nasional pendidikan (SNP). Khususnya SNP untuk SMK/MAK. Berikut ditunjukkan beberapa hasil penelitian relevan dengan penelitian ini.

Hasil penelitian Puspita (2017) menunjukkan bahwa: (1) implementasi penjaminan mutu di SD Muhammadiyah 1 Ketelan Surakarta sudah berjalan dengan baik. hal ini dapat dibuktikan dengan tercapainya seluruh delapan standar nasional pendidikan yang telah dilakukan SD Muhammadiyah 1 Ketelan Surakarta. (2) hambatan yang dihadapi dalam sistem penjaminan mutu di SD Muhammadiyah 1 Ketelan adanya 2 kurikulum yang diterapkan, alokasi waktu, dan pembiayaan (3) solusi yang dilakukan untuk mengatasi hambatan sistem penjaminan mutu di SD Muhammadiyah 1 Ketelan Surakarta menyiapkan program yang bisa memfasilitasi kurikulum yang berbeda, monitoring pembelajaran, mengembangkan badan usaha milik sekolah. Perbedaan dengan penelitian ini, dari metode penelitian dan tempat penelitian. Metode penelitian yang digunakan pada penelitian sebelumnya adalah metode deskriptif kualitatif yang dilakukan di SD Muhammadiyah 1 Ketelan Surakarta. Sedangkan, penelitian ini dilakukan dengan metode evaluasi CIPP di SMKN 3 Singaraja.

Penelitian Sodiq (2017) tentang pelaksanaan penjaminan mutu pendidikan di SMK Negeri 1 Magelang meliputi: penetapan standar mutu, pemetaan mutu, penyusunan rencana pemenuhan mutu, pelaksanaan pemenuhan mutu, dan evaluasi pemenuhan mutu. Penelitian ini menggunakan model evaluasi "Goal Free Evaluation Model'. Subyek penelitian ini adalah Kepala Sekolah, Wakil Kepala Sekolah, Kepala Tata Usaha, Ketua Jurusan, dan Tim Renbang (Perencanaan dan Pengembangan) SMK Negeri 1 Magelang. Instrumen penelitian menggunakan angket, lembar dokumentasi, dan pedoman wawancara. Teknik analisis data dengan statistic deskriptif kuantitatif dan statistik deskriptif kualitatif. Hasil penelitian ini menunjukkan bahwa: (1) penetapan standar mutu mencapai $97 \%$ mencakup dasar dalam penetapan standar mutu (100\%) dan pihak yang terlibat dalam penetapan standar mutu (94\%), (2) pemetaan mutu mencapai $92 \%$ mencakup pemetaan berdasarkan hasil EDS (100\%), pemetaan pada 8 SNP (86\%), pemetaan didukung bukti fisik (100\%), dan pemetaan menggambarkan mutu sekolah (83\%), (3) penyusunan rencana pemenuhan mutu mencapai $96 \%$ mencakup persiapan sekolah (100\%), dasar penyusunan $(98 \%)$, isi $(99 \%)$, pengesahan (97\%), dan sosialisasi (86\%), (4) pelaksanaan pemenuhan mutu mencapai $90 \%$ mencakup sekolah melakukan pemenuhan 8 SNP (97\%) dan komitmen komponen sekolah (83\%), dan (5) evaluasi pemenuhan mutu mencapai 97\% mencakup evaluasi melalui EDS (100\%), tujuan evaluasi (97\%), dan tahapan evaluasi (93\%). Sodiq (2017) mengunakan model evaluasi "Goal Free Evaluation Model' sedangkan penelitian ini menggunakan model CIPP.

Penelitian Simarmata (2015) menunjukkan penjaminan mutu di SMAN 3 Kota Jambi telah terlaksana dengan baik namun terdapat beberapa kendala dalam pelaksanaannya yakni kurangnya otonomi kepemimpinan manajerial kepala sekolah sehingga dan kurangnya kesadaran guru akan budaya mutu. Dalam penelitian ini, penjminan dari atas adalah penjaminan dengan pendekatan top-down oleh penyelenggara satuan pendidikan melalui monitoring, pengawasan, dan supervisi. Di SMA Negeri 3 Kota Jambi, penjaminan dari atas dimulai dari Pemerintah lalu turun ke Pemprov kemudian Pemkot/kab dan terakhir Satuan Pendidikan. Sejauh pengamatan peneliti, pelaksanaan penjaminan mutu di SMA N 3 Kota Jambi berdampak positif kepada stake holders. Meskipun belum ada data empiris tentang hal ini namun diketahui bahwa SMA N 3 Kota Jambi merupakan salah satu sekolah favorit di Kota Jambi. Selain itu, di sekolah ini, seperti yang peneliti amati, para civitas academica di sekolah ini seperti siswa dan guru cukup disiplin dalam process pembelajaran.

SMKN 3 Singaraja telah memiliki TPMPS SPMI yang bertugas terpenuhinya minimal delapan standar nasional pendidikan (SNP) SMK, namun sampai saat ini belum dilakukan evaluasi efektivitas pelaksanaan SPMI. Kualitas mutu pendidikan distandarisasi dengan merumuskan Sistem Penjaminan Mutu Internal (SPMI) dan mengimplementasikannya melalui process Perencanaan, Pelaksanaan, Evaluasi, Pengendalian, dan Peningkatan (PPEPP). Namun perlu di teliti lebih lanjut apakah perencanaan SPMI sudah mempertimbangkan kebutuhan SMKN 3 Singaraja dan memastikan terpenuhinya delapan standar nasional pendidikan. Process PPEPP sudahkah dilaksanakan dengan baik per siklusnya. Hasil yang dicapai apakah sesuai dengan tujuan yang telah dirumuskan pada saat perencanaan. Oleh karena itu maka peneliti tertarik untuk melakukan penelitian yang berjudul "Studi Evaluasi Implementasi Sistem Penjaminan Mutu Internal (SPMI) Dalam Rangka Meningkatkan Budaya Mutu Sekolah Di Smk Negeri 3 Singaraja". 
Tujuan penelitian ini untuk mengetahui: (1) efektivitas implementasi SPMI ditinjau dari komponen contex; (2) efektivitas pelaksanaan implementasi SPMI ditinjau dari komponen input; (3) efektivitas implementasi SPMI ditinjau dari komponen process: (4) efektivitas implementasi SPMI di ditinjau dari komponen product; (5) efektivitas implementasi SPMI ditinjau dari komponen contex, input, process, dan product; (6) kendala yang menjadi penghambat pelaksanaan implementasi SPMI di SMKN 3 Singaraja; (7) solusi yang dilakukan sehingga implementasi SPMI di SMKN 3 Singaraja dapat lebih efektif

\section{Metode}

Penelitian yang peneliti lakukan ini termasuk penelitian deskriptif kuantitatif. Penelitian deskriptif adalah penelitian yang dilakukan untuk mengetahui variabel mandiri, baik satu variabel atau lebih (independen) tanpa membuat perbandingan, atau menghubungkan antara variabel satu dengan variabel yang lain. (Sugiyono, $2005: 11$ ) Dari pendapat tersebut dapat peneliti jelaskan bahwa: Peneliti tidak bermaksud untuk menguji hipotesis tetapi hanya ingin mengetahui dan mendeskipsikan gejala atau fenomena yang ada di lapangan sesuai dengan apa adanya tentang yakni efektivitas implementasi SPMI di SMKN 3 Singaraja Kabupaten Buleleng. Pendekatan yang dipergunakan dalam penelitian ini adalah penelitian kuantitatif. Dalam penelitian ini, peneliti mencoba untuk mencermati individu atau subjek penelitian secara mendalam dan mencoba mengungkap personal yang ada pada diri kepala sekolah, serta mencoba mencari informasi berkenaan dengan tugas dan tanggung jawabnya sebagai kepala sekolah, sehingga dapat diketahui tentang efektivitas implementasi SPMI di SMKN 3 Singaraja Kabupaten Buleleng dengan CIPP.

Agung dan Koyan (2016: 5) menyatakan evaluasi program adalah kegiatan yang bertujuan untuk mengukur keberhasilan sesuatu yang telah direncanakan dan akan dilaksanakan. Metode ini bersifat sistematik untuk mengumpulkan, menganalisis, dan memakai informasi untuk menjawab pertanyaan dasar mengenai program. Terdapat delapan jenis model evaluasi menurut Stufflebeam et al. (dalam Agung dan Koyan, 2016: 33) menjelaskan bahwa evaluasi merupakan process menjelaskan, memperoleh, dan menyediakan informasi yang berguna bagi pengambilan keputusan yang terbaik.

Stufflebeam (dalam Agung dan Koyan, 2016: 33-39) model CIPP memiliki empat unsur yang berkesinambungan. Pertama, evaluasi contex $(X 1)$ utamanya mengarah pada identifikasi kekuatan dan kelemahan organisasi dan pada pemberian masukan untuk memperbaiki organisasi. Kedua, evaluasi input teristimewa dimaksudkan untuk membantu menentukan program guna melakukan perubahan-perubahan yang dibutuhkan. Ketiga, evaluasi process pada dasarnya memeriksa pelaksanaan rencana yang telah ditetapkan. Keempat, evaluasi product bertujuan untuk mengukur, menafsirkan, dan menilai capaian-capaian program.

Penelitian ini dirancang sebagai studi kasus karena berusaha mendekripsikan dan menganalisis implementasi SPMI di SMKN 3 Singaraja Kabupaten Buleleng. Oleh karena itu semua data yang terkumpul merupakan kejadian-kejadian atau process yang terjadi terkait implementasi SPMI di SMKN 3 Singaraja kabupaten Buleleng. Dan kemudian merunut kebelakang melalui data tersebut untuk menentukan faktor-faktor penyebab terjadinya peristiwa yang dileliti.

Pada prinsifnya penelitian ini menggunakan pendekatan evaluatif. Secara epistemologi dalam pengumpulan data menggunakan pendekatan objektif dan subjektif, karena disamping berpedoman pada data yang telah tersedia, dalam suatu dokumen yang telah tersusun, juga berdasarkan observasi kepada subjek penelitian. Secara ontologis, penelitian ini mempergunakan pendekatan evaluasi yang berorientasi pada tujuan dan evaluasi berorientasi pada implementasi SPMI di SMKN 3 Singarajadengan tehnik analisis data yang dipergunakan adalah deskriptif kuantitatif.

Sedang evaluasi berorientasi pada implementasi SPMI di SMKN 3 Singaraja, bertujuan untuk mencari solusi dalam memecahkan masalah yang dihadapi, memberi masukan terhadap program dimasa datang. Jika dikaitkan dengan jenis data yang dibutuhkan maupun analisa yang dipergunakan maka sebatas memberi masukan dan dianalisis secara kulitatif serta merupakan penelitian Studi kasus yang tidak dapat digeneralisasi sehingga apapun kesimpulan yang diambil hanya berlaku pada implementasi SPMI di SMKN 3 Singaraja.

Penelitian ini dilaksanakan di SMKN 3 Singaraja. Alasan penentuan sekolah ini adalah karena sekolah tersebut telah mengimplementasikan SPMI. Waktu penelitian dimulai dari Januari 2020 sampai dengan Maret 2020. Sedangkan penyusunan laporan dilakukan sejak awal penelitian. 
Populasi dalam penelitian ini adalah semua civitas akadememika SMKN 3 Singaraja yang memahami implementasi SPMI, antara lain 45 orang ( terdiri dari kepala sekolah, wakasek, dan TPMS), 28 orang pegawai, dan 185 orang guru. Jumlah keseluruhan populasi 258 orang. Data dalam penelitian ini diambil dengan sampling purposive dengan jumlah sampel dihitung berdasarkan Nomogram Harry King yaitu 50\% dari jumlah populasi yaitu 129 orang. Secara rinci terdiri dari 23 (kepala sekolah, wakasek, TPMPS), 14 orang pegawai dan 92 orang guru di SMKN 3 Singaraja.

Instrumen yang digunakan adalah kuesioner dengan sekala likert yang telah dilakukan uji ahli dan uji coba validitas dan reliabilitas lapangan, diperoleh dari 152 butir pernyataan dalam kuesioner, tidak valid satu sehingga digunakan 151 butir pernyataan. Data dianalisis dengan statistic deskriptif dan evaluasi CIPP menggunakan transformasi data ke T skor kemudian dimaasukkan ke dalam kuadran Glickman untuk mengetahui efektivitas implementasi SPMI di SMKN 3 Singaraja (Agung, 2016: 17-76; Agung \& Koyan, 2016: 37).

\section{Hasil dan Pembahasan}

Hasil uji statistik deskriptif data veariabel contex (X1), input (X2), process (X3), dan product (X4) ditunjukkan pada Tabel 01.

Tabel 1. Statistik Deskriptif Veariabel Contex (X1), Input (X2), Process (X3), dan Product (X4).

\begin{tabular}{lrccc}
\hline \multicolumn{1}{c}{ Statistik } & Contex (X1) & Input (X2) & Process (X3) & Product (X4) \\
\hline $\mathrm{N}$ & 129,00 & 129,00 & 129,00 & 129,00 \\
Rerata & 35,33 & 32,71 & 41,60 & 58,62 \\
Median & 36,00 & 33,00 & 41,00 & 58,00 \\
Modus & 36,00 & 33,00 & 43,00 & 56,00 \\
Std. Deviasi & 3,91 & 3,71 & 3,82 & 5,25 \\
Varians & 15,29 & 13,75 & 14,57 & 27,60 \\
Skewness & 0,06 & $-0,23$ & $-0,11$ & 0,35 \\
Kurtosis & $-0,23$ & $-0,43$ & 0,10 & $-0,43$ \\
Range & 19,00 & 17,00 & 20,00 & 23,00 \\
Minimum & 27,00 & 23,00 & 31,00 & 47,00 \\
Maximum & 46,00 & 40,00 & 51,00 & 70,00 \\
\hline Jumlah & $\mathbf{4 5 5 8 , 0 0}$ & $\mathbf{4 2 2 0 , 0 0}$ & $\mathbf{5 3 6 6 , 0 0}$ & $\mathbf{7 5 6 2 , 0 0}$ \\
\hline
\end{tabular}

Tabulasi data hasil penelitian variabel contex (X1) dari 129 orang responden ditunjukkan pada Tabel 02.

Tabel 02. Distribusi Frekuensi Skor Variabel Contex (X1)

\begin{tabular}{ccccccc}
\hline No. & \multicolumn{2}{c}{ Interval Kelas } & & $\begin{array}{c}\text { Nilai } \\
\text { Tengah }\end{array}$ & $\begin{array}{c}\text { Frekuensi } \\
\text { Absolut }\end{array}$ & $\begin{array}{c}\text { Frekuensi } \\
\text { Relatif (\%) }\end{array}$ \\
\hline 1 & 25 & - & 27 & 26 & 3 & 2 \\
2 & 28 & - & 30 & 29 & 12 & 9 \\
3 & 31 & - & 33 & 32 & 27 & 21 \\
4 & 34 & - & 36 & 35 & 40 & 31 \\
5 & 37 & - & 39 & 38 & 29 & 22 \\
6 & 40 & - & 42 & 41 & 13 & 10 \\
7 & 43 & - & 45 & 44 & 4 & 3 \\
8 & 46 & - & 48 & 47 & 1 & 1 \\
\hline
\end{tabular}


Berdasarkan Tabel 1 data variabel contex (X1) 31\% pada kelas interval dengan nilai tengah 35 dan $22 \%$ pada kelas interval dengan nilai tengah 38 , dari nilai maksimal 50 . Pada variabel variabel contex (X1) diperoleh bahwa Standar SPMI yang dibuat di SMKN 3 Singaraja belum melampaui Standar Nasional Pendidikan. Perencanaan SPMI belum mengacu hasil hasil Analisis SWOT, namun mengacu pada aturan formal: a) Undang-undang Sistem Pendidikan Nasional No. 20 Tahun 2003; b) Standar Nasional Pendidikan tahun 2005, serta perundangan lain dalam pendidikan; c) Permendikbud No.28 Tahun 2016 tentang Sistem Penjaminan Mutu Pendidikan Dasar dan Menengah; dan d) Standar Internasional ISO 9001:2008 berbasis IWA 2: 2007. Sehingga dianggap ada beberapa bagian standar yang belum sesuai dengan kebutuhan, situasi, kondisi, dan daya dukung riil sekolah. Standar Internasional ISO 9001:2008 dimasukkan sebagai acuan pembuatan SPMI sebagai adaptasi penggunaan standar ini sebelumnya. Namun, penyusunan standar SPMI telah selaras dan mendukung pencapaian visi dan misi sekolah.

Tabulasi data hasil penelitian variabel input (X2) dari 129 orang responden ditunjukkan pada Tabel 03.

Tabel 03. Distribusi Frekuensi Skor Variabel Input (X2)

\begin{tabular}{c|ccc|c|c|c}
\hline No. & \multicolumn{3}{|c|}{ Interval Kelas } & $\begin{array}{c}\text { Nilai } \\
\text { Tengah }\end{array}$ & $\begin{array}{c}\text { Frekuensi } \\
\text { Absolut }\end{array}$ & $\begin{array}{c}\text { Frekuensi } \\
\text { Relatif (\%) }\end{array}$ \\
\hline 1 & 22 & - & 24 & 23 & 1 & 1 \\
2 & 25 & - & 27 & 26 & 12 & 9 \\
3 & 28 & - & 30 & 29 & 23 & 18 \\
4 & 31 & - & 33 & 32 & 38 & 29 \\
5 & 34 & - & 36 & 35 & 33 & 26 \\
6 & 37 & - & 39 & 38 & 18 & 14 \\
7 & 40 & - & 42 & 41 & 4 & 3 \\
\hline \multicolumn{7}{|r|}{ Jumlah } \\
\hline
\end{tabular}

Tabel 03 menunjukkan data variabel input (X2) 29\% masuk kelas interval dengan nilai tengah 32 , dan $26 \%$ masuk kelas interval dengan nilai tengah 35 . Kelemahan yang ditunjukkan pada variabel input berdasarkan hasil kuesioner dan wawancara antara lain: (1) Masih adanya rangkap jabatan, misalnya wakasek dan kaprodi yang juga masuk sebagai anggota TPMPS, mestinya TPMPS independent. Hal tersebut akan berdampak pada saat evaluasi khususya audit, ada pihak yang menjadi auditor sekaligus anggota dari bagian yang dinilai. Semestinya, TPMS dibentuk dari para guru atau staf yang belum memegang jabatan, agar benar-benar TPMS independent; (2) SMKN 3 Singaraja belum memiliki anggaran khusus untuk SPMI yang dikelola mandiri oleh TPMPS. Selain itu, dana yang diambil dari dana sekolah masih sangat minim untuk operasional PPEPP SPMI; dan (3) TPMPS belum memiliki otonomi dalam mengelola dana khusus untuk pelaksanaan SPMI, dana diberikan sekolah secara insidental saat akan dilakukan kegiatan dan tanpa ada kepastian jumlah yang jelas.

Tabulasi data hasil penelitian variabel process (X3) dari 129 orang responden ditunjukkan pada Tabel 04.

Tabel 04. Distribusi Frekuensi Skor Variabel Process (X3)

\begin{tabular}{|c|c|c|c|c|c|c|}
\hline \multirow{2}{*}{$\begin{array}{c}\text { No. } \\
1\end{array}$} & \multicolumn{3}{|c|}{ Interval Kelas } & \multirow{2}{*}{$\begin{array}{c}\begin{array}{c}\text { Nilai } \\
\text { Tengah }\end{array} \\
31\end{array}$} & \multirow{2}{*}{$\begin{array}{c}\begin{array}{c}\text { Frekuensi } \\
\text { Absolut }\end{array} \\
2\end{array}$} & \multirow{2}{*}{$\begin{array}{c}\text { Frekuensi } \\
\text { Relatif (\%) } \\
2\end{array}$} \\
\hline & 30 & - & 32 & & & \\
\hline 2 & 33 & - & 35 & 34 & 7 & 5 \\
\hline 3 & 36 & - & 38 & 37 & 15 & 12 \\
\hline 4 & 39 & - & 41 & 40 & 41 & 32 \\
\hline
\end{tabular}




\begin{tabular}{clllccc}
\hline 5 & 42 & - & 44 & 43 & 37 & 29 \\
6 & 45 & - & 47 & 46 & 19 & 15 \\
7 & 48 & - & 50 & 49 & 7 & 5 \\
8 & 51 & - & 53 & 52 & 1 & 1 \\
\hline
\end{tabular}

Berdasarkan Tabel 04 diperoleh data 32\% data masuk nilai tengah 40 dan 29\% data masuk nilai tengah 43 , dari nilai maksimal 60 . Beberapa kelemahan yang diperoleh berdasarkan hasil observasi, wawancara, dan penyebaran kuesioner: (1) Persiapan PPEPP SPMI di SMKN 3 SIngaraja belum melibatkan semua pihak yang berkepentingan misalnya rekanan magang, pihak pengguna output, wakil siswa dan orang tua siswa; (2) Perencanaan telah dilakukan melalui rapat dan menghasilkan tupoksi, namun belum menghasilkan roadmap yang jelas terkait pengembangan SPMI di SMKN 3 Singaraja; (3) SMKN 3 Singaraja belum memiliki process penjadwalan PPEPP SPMI yang jelas. Artinya, belum memiliki batas waktu yang jelas dalam target pelaksanaan evaluasi, pengendalian, dan peningkatan lebih lanjut; (4) SMKN 3 Singaraja belum memiliki target pencapaian pada setiap langkah PPEPP SPMI yang dijadwalkan. Namun, pelaksanaan kegiatan di SMKN 3 Singaraja sudah memenuhi standar BAN SM dengan tambahan implementasi Standar Internasional ISO 9001:2008 berbasis IWA 2: 2007.

Tabulasi data hasil penelitian variabel product (X4) dari 129 orang responden ditunjukkan pada Tabel 05.

Tabel 05. Distribusi Frekuensi Skor Variabel Product

\begin{tabular}{ccccccc}
\hline No. & & Interval Kelas & & $\begin{array}{c}\text { Nilai } \\
\text { Tengah }\end{array}$ & $\begin{array}{c}\text { Frekuensi } \\
\text { Absolut }\end{array}$ & $\begin{array}{c}\text { Frekuensi } \\
\text { Relatif }(\%)\end{array}$ \\
\hline 1 & 47 & - & 49 & 48 & 5 & 4 \\
2 & 50 & - & 52 & 51 & 5 & 4 \\
3 & 53 & - & 55 & 54 & 26 & 20 \\
4 & 56 & - & 58 & 57 & 35 & 27 \\
5 & 59 & - & 61 & 60 & 19 & 15 \\
6 & 62 & - & 64 & 63 & 18 & 14 \\
7 & 65 & - & 67 & 66 & 11 & 9 \\
8 & 68 & - & 70 & 69 & 10 & 8 \\
\hline
\end{tabular}

Berdasarkan Tabel 4 diperoleh data variabel product (X4) 27\% pada nilai tengah 57 dan $20 \%$ pada nilai tengah 54 , dari nilai maksimal 85 . Berdasarkan asil pengisian kuesioner, process observasi, dan wawancara masih ada beberapa kelemahan pada variabel product (X4) antara lain: (1) SMKN 3 Singaraja belum mencapai standar pendidikan melampaui standar pendidikan nasional; (2) Belum dilakukan evaluasi/diaudit hasil pelakasanaan SPMI di SMKN 3 Singaraja sehingga belum diketahui signifikan tidaknya peningkatan yang diakibatkan. Namun, hasil observasi dan wawancara menunjukkan sudah adanya peningkatan disiplin administrasi dan process pembelajaran di kelas; dan (3) Tidak ada peningkatan sarana dan prasarana di SMKN 3 Singaraja akibat implementasi SPMI, karena sudah dianggap cukup dan memenuhi standar.

Setelah transformasi data ke T skor kemudian dimasukkan ke dalam kuadran Glickman untuk mengetahui efektivitas implementasi SPMI di SMKN 3 Singaraja ditunjukkan pada Tabel 06. 
Tabel 07. Kuadran Glickman

\begin{tabular}{ccccc}
\hline $\begin{array}{c}\text { Variabel Contex } \\
(X 1)\end{array}$ & $\begin{array}{c}\text { Variabel } \\
\text { Input (X2) }\end{array}$ & $\begin{array}{c}\text { Variabel } \\
\text { Process (X3) }\end{array}$ & $\begin{array}{c}\text { Variabel } \\
\text { Product (X4) }\end{array}$ & Keputusan \\
\hline+ & - & + & + & Efektif \\
\hline
\end{tabular}

Tabel 07 menunjukkan hasil evaluasi variabel contex (X1) berdasarkan skor $T$ menunjukkan hasil positif $(+)$ karena landasan dasar penyusunan SPMI sudah sesuai yaitu Permendikbud no. 28 th. 2016 dan memenuhi Standar Nasional Pendidikan. Selain itu, SPMI yang dibuat di SMKN 3 SIngaraja sudah selaras dan mendukung pencapaian visi dan misi sekolah. Serta, tujuan Penyusunan SPMI di SMKN 3 Singaraja sudah sesuai dan mendukung pencapaian visi dan misi sekolah.

Hasil evaluasi variabel input (X2) berdasarkan skor T menunjukkan hasil (-) karena masih menunjukkan rangkap jabatan sehingga sifat independen dari TPMPS. Masih rendahnya dukungan sarana prasarana untuk pelaksanaan SPMI di SMKN 3 SIngaraja. Hal tersebut dapat dilihat dari belum adanya ruang khusus yang disediakan untuk TPMPS. Belum ada media publikasi dan internet khusus yang disediakan untuk mendukung sosialisasi SPMI dan pelaksanaanya, sehingga masih mengandalkan sosialisasi melalui rapat sekolah saja. Masih minimnya anggaran khusus yang disediakan untuk SPMI yang benar-benar dikelola oleh mandiri oleh TPMPS. Kepala sekolah mengeluarkan SK Nomor: 800/1360/SMKN3.SGR/2019 tentang pembentukan Tim Penjaminan Mutu Pendidikan Sekolah (TPMPS) SMKN 3 Singaraja dan uraian tugasnya. Namun, belum ada aturan kebijakan yang dikeluarkan oleh kepala sekolah terkait pelaksanaan SPMI, misalnya terkait hak dan kewajiban TPMPS, kepastian sumber dan alokasi dana pelaksanaan, serta regulasi siklus PPEPP pelaksanaan SPMI.

Hasil evaluasi variabel process (X2) berdasarkan skor T menunjukkan hasil positif (+) karena persiapan PPEPP SPMI di SMKN 3 SIngaraja dilakukan melalui rapat sekolah dan telah menghasilkan TPMPS dan uraian tugas masing-masing bagian. SMKN 3 Singaraja memiliki target pencapaian yang mendukung pencapaian tujuan sekolah. SMKN 3 SIngaraja memiliki dokumen bukti pelaksanaan PPEPP SPMI, berupa formulir, foto, dan bukti administrasi lainnya. Pelaksanaan PPEPP SPMI di SMKN 3 SIngaraja memenuhi prinsip mandiri, terstandar, akurat, sistemik dan berkelanjutan, kontrol, dan terdokumentasi. Implementasi SPMI di SMKN 3 Singaraja baru berjalan mulai 2019, belum di adakan process evaluasi, pengendalian, dan peningkatan, belum lewat satu siklus.

Hasil evaluasi variabel product (X4) berdasarkan skor T menunjukkan hasil positif $(+)$ karena dokumen SPMI yang dimiliki SMKN 3 Singaraja sudah lengkap baik dokumen dokumen kebijakan SPMI, manual SPMI, standar dalam SPMI, dokumen formulir serta dokumen pendukung SPMI. SMKN 3 Singaraja mencapai standar pendidikan relevan dengan Standar Pendidikan nasional, malah telah melaksanakan standar internasional ISO 9001:2008 berbasis IWA 2: 2007. Pelaksanaan SPMI di SMKN 3 Singaraja berdasarkan hasil wawancara dan pengisian kuesioner memiliki efek positif bagi peningkatan kualitas pendidikan secara umum, kualitas kinerja pimpinan sekolah, kualitas kinerja guru, kualitas kinerja staf TU, kualitas kinerja TPMPS, dan kualitas pembelajaran. Selain itu, pelaksanaan SPMI mendorong sivitas akademina SMKN 3 Singaraja lebih tertib administrasi.

Hasil skor T pada Tabel 5 menunjukkan variabel contex (X1) positif $(+)$, variabel input (X2) negatif (-), variabel process (X3) positif, dan variabel product (X4) positif (+), sehingga hasil evaluasi CIPP pada Kuadran Glickman (+-++) menunjukkan implementasi sistem penjaminan mutu internal (SPMI) dalam rangka mewujudkan budaya mutu di SMKN 3 Singaraja termasuk kategori efektif.

Kendala yang menjadi penghambat pelaksanaan implementasi SPMI di SMKN 3 Singaraja adalah: (1) belum adanya alokasi dana pasti untuk pelaksanaan PPEPP SPMI yang dikelola mandiri oleh TPMPS sehingga penjadwalan tahap PPEPP sulit direncanakan; dan (2) belum adanya ruang, alat, dan bahan yang khusus disediakan untuk TPMPS sebagai pendukung pelaksanaan PPEPP.

Solusi yang dilakukan sehingga implementasi SPMI di SMKN 3 Singaraja dapat lebih efektif adalah: (1) membuat alokasi anggaran khusus untuk pelaksanaan PPEPP SPMI di SMKN 3 Singaraja yang dapat dikelola secara mandiri oleh TPMPS; (2) Menyediakan ruang, alat, dan bahan yang mendukung pelaksanaan PPEPP oleh TPMPS. 


\section{Simpulan dan Saran}

Berdasarkan hasil dan pembahasan maka disimpulkan beberapa hal antara lain: (1) efektivitas implementasi SPMI Singaraja ditinjau dari komponen contex (X1) di SMKN 3 Singaraja, masuk skor T positif; (2) efektivitas pelaksanaan implementasi SPMI ditinjau dari komponen input di SMKN 3 Singaraja, masuk skor T negatif; (3) efektivitas implementasi SPMI ditinjau dari komponen process di SMKN 3 Singaraja, masuk skor T positif: (4) efektivitas implementasi SPMI di ditinjau dari komponen product SMKN 3 Singaraja, masuk skor T positif; (5) efektivitas implementasi SPMI ditinjau dari komponen contex (X1), input, process, dan product di SMKN 3 Singaraja berdasarkan skor T pada kuadran Glickman masuk kategori efektif; (6) Kendala yang menjadi penghambat pelaksanaan implementasi SPMI di SMKN 3 Singaraja adalah: (a) belum adanya alokasi dana pasti untuk pelaksanaan PPEPP SPMI yang dikelola mandiri oleh TPMPS dan belum adanya ruang, alat, serta bahan pendukung pelaksanaan PPEPP; (7) Solusi yang dilakukan sehingga implementasi SPMI di SMKN 3 Singaraja dapat lebih efektif adalah: (1) mengalokasikan anggaran khusus untuk pelaksanaan PPEPP SPMI di SMKN 3 Singaraja yang dapat dikelola secara mandiri oleh TPMPS dan Menyediakan ruang, alat, dan bahan yang mendukung pelaksanaan PPEPP oleh TPMPS.

\section{Daftar Pustaka}

Agung, A.A. Gede dan W. Koyan. 2016. Evaluasi Program Pendidikan (Fungsi Manajemen Kontrol). Singaraja: Universitas Pendidikan Ganesha.

Agung, A.A. Gede. 2016. Statistika Dasar untuk Pendidikan. Yogyakarta: Deepublish

Agung, A.A. Gede. 2017. Evaluasi Pendidikan (Edisi-4). Singaraja: Undiksha.

Agung, A.A. Gede. 2017a. Statistika Inferensial untuk Pendidikan (Disertai Aplikasi SPSS). Singaraja: Undiksha.

Agung, A.A. Gede. 2018. Metodologi Penelitian Kuantitatif (Perspektif Manajemen Pendidikan). Singaraja: Undiksha.

Sodiq, R. 2017. Evaluasi penjaminan mutu pendidikan Di SMK Negeri 1 Magelang. Skripsi.Yogyakarta: Jurusan Pendidikan Teknik Otomotif UNY.

Simarmata, J. 2015. Analisis Implementasi Penjaminan Mutu Di Sma Negeri 3 Kota Jambi. Jurnal IImiah Universitas Batanghari Jambi, Vol.15, No.4: 54-62.

Kemendikbud. 2018. Perangkat Instrumen Pemetaan Mutu Pendidikan Dasar dan Menengah Tingkat Sekolah Kejuruan. Jakarta: Dirjen PDM.

Kemendikbud. 2016. Pedoman Umum Sistem Penjaminan Mutu Pendidikan Dasar dan mengengah. Jakarta: Dirjen PDM.

Permendikbud. 2018. Standar Nasional Pendidikan Sekolah Menengah Kejuruan dan Madrasah Aliyah Kejuruan. E-book diunduh dari jdih.kemdikbud.go.id.

Puspita, A.C. 2017. Implementasi Penjaminan Mutu Di Sekolah Dasar Muhammadiyah 1 Ketelan Surakarta. Skripsi (tidak diterbitkan): Prodi PGSD Universitas Muhamadyah Surakarta.

Wahyujaya, Koesmaryono yonny, dan Yulianda Fredinan. 2015. Kajian sistem pembelajaran sebagai upaya peningkatan sistem penjaminan mutu (jurnal kependidikan, Volume 45, Nomor 1, Mei, Halaman 90-104). Bogor: Institut Pertanian.

Yuniarini, P. Dina. 2019. Evaluasi Efektivitas Penggunaan Dana Bantuan Operasional Penyelenggaraan (BOP) Paket C Pada Pusat Kegiatan Belajar Masyarakat (PKBM) Wldya Santana Kabupaten Badung Tahun 2018. Tesis. Singaraja: Prodi AP Pascasarjana Undiksha. 